\title{
RENAL TUBULAR SECRETION AND REABSORPTION OF ORGANIC BASES IN THE DOG*
}

\author{
By JORGE TORRETTI, $†$ I. M. WEINER AND GILBERT H. MUDGE
}

(From the Department of Pharmacology and Experimental Therapeutics, The Johns Hopkins

University, School of Medicine, Baltimore, Md.)

(Submitted for publication October 26, 1961 ; accepted December 14, 1961)

The dependence of the renal excretion of relatively weak organic bases on urine $\mathrm{pH}$ has been repeatedly demonstrated for both man (1-3) and the dog (4). Many investigators have considered this as an example of non-ionic diffusion (5), according to which the renal tubule is permeable to the non-ionic form but impermeable to the ionized particle. The non-ionic form tends to reach an equilibrium concentration on either side of the tubular epithelium. Thus, the concentration of total base, both ionized and non-ionized, is determined by the hydrogen ion gradient across the membrane. If the urine is more acid than the plasma, the urinary concentration of total base will be higher than in plasma; the opposite will obtain in a urine more alkaline than plasma. When clearance data have been evaluated in these terms, the mechanism of non-ionic diffusion has been considered adequate to explain a wide range of excretion rates varying from net tubular secretion to net tubular reabsorption (6). ${ }^{1}$

* Supported by Grant H-4015 from the National Heart Institute. A preliminary report was presented before the Fall Meeting of the American Society for Pharmacology and Experimental Therapeutics, Seattle, Wash., 1960.

† Rockefeller Foundation Fellow. Present address: Institute of Physiology and Department of Medicine, University of Chile School of Medicine, Santiago, Chile.

1 Bidirectional transport poses a difficult semantic problem. In this paper, secretion and reabsorption are defined in terms of direction of transport without implication as to underlying mechanism, secretion being movement from peritubular fluid into the tubule, and reabsorption being in the opposite direction. When referring to a given segment of the nephron, one may consider either net segmental secretion or net segmental reabsorption, such terms being defined as a function of the quantity of substance transported. Considering the tubule as a whole, net tubular reabsorption indicates that the total quantity transported in a reabsorptive direction exceeds the amount which is secreted; net tubular secretion means that the total secreted exceeds that which is reabsorbed. Net tubular reabsorption (or secretion) may be -calculated directly using the amount filtered at the glo-
A totally different aspect of organic base excretion (with strong bases, mostly quaternary ammonium compounds) has been studied with the in vitro technique, using slices of dog kidney cortex (7), and the in vivo methods of the renal portal preparation in the chicken $(8,9)$ and regular clearances in the dog (10). Under these conditions the administration of one quaternary base inhibits the accumulation or tubular secretion of another. This apparent competition has been taken as evidence for an active transport process in a secretory direction. This system depends on cellular activity and is susceptible to metabolic inhibitors. $^{2}$ The findings have been summarized by Peters in an excellent review (11).

Thus, according to the above, net tubular secretion has been generally attributed to two entirely different mechanisms; i.e., passive non-ionic diffusion for weak bases (amines), and active transport for strong bases (onium compounds). However, there has been some evidence that these two classes of compounds may share a common active transport system. Tolazoline, an amine, has been considered to have a maximal rate of net tubular secretion characteristic of active transport in the

merulus as a reference point. The demonstration of net tubular secretion in vivo constitutes the main evidence that a secretory process is operative. However, secretion may occur even though clearance measurements indicate net tubular reabsorption.

2 The term "active transport" continues to be ambiguous due to the fact that its definition depends largely on the number of parameters which can be directly measured or indirectly estimated in any particular type of experiment. In the present studies, competition for transport is the major criterion indicating that transport does not occur by simple diffusion. The phenomenon of competition implies that essential cellular components are rate limiting. While the term "active transport" is used with the above connotation, it is clear that its exact mechanism remains unknown. This is true of most active transport systems, no matter what definition is employed. 
$\operatorname{dog}(12)$. In the chicken, this compound depresses the net tubular secretion of onium compounds and is itself secreted (13).

Despite these and many related observations, the relationship between active transport and $\mathrm{pH}-$ dependent excretion has not been established. There are several possibilities. It has been suggested by Baer, Paulson, Russo and Beyer (14) that the active transport system is itself $\mathrm{pH}$ dependent. For reasons which will be presented in detail in the Discussion, this seems improbable. Therefore, in the design of the present experiments, the $\mathrm{pH}$-dependent process was considered to be one of diffusion which might coexist with an active secretory process. Since this dual mechanism has been demonstrated for organic acids in the dog (15), it seemed to be a plausible hypothesis for bases. In this scheme non-ionic diffusion would occur primarily in a reabsorptive direction and would not account for high rates of net tubular secretion, as has been postulated by others (6).

Experimental evidence was therefore sought to determine whether phenomena consistent with competition for secretion could be demonstrated in the dog. Clearances were conducted with rigid control of urine $\mathrm{pH}$ and volume so that an observed decrease in excretion could not be attributed to an increase in passive reabsorption. Previous attempts to demonstrate competition in the dog had been reported as negative $(12,16)$. In addition, the phenomenon of non-ionic diffusion has been examined in its quantitative aspects to ascertain the extent to which it is applicable to the measured rates of excretion.

The findings are consistent with the hypothesis that organic bases, like certain organic acids, are excreted by a three-component mechanism; i.e., filtration, active secretion, and passive reabsorption. The independent studies recently reported by Smith, Peake and Peters (17) have supported this interpretation.

\section{METHODS}

Mongrel female dogs were studied with standard clearance techniques. Details of the methods employed in this laboratory have been previously reported (15). In many experiments the animals were unanesthetized. However, in some instances untrained dogs were anesthetized with intravenous pentobarbital (30 $\mathrm{mg}$ per $\mathrm{kg}$ ). This was considered necessary because of the marked toxicity ex- hibited by the bases in the relatively large doses required to obtain plasma concentrations sufficiently high to permit accurate measurement. When dogs were studied on repeated occasions, filtration rate was normal and appeared not to have been influenced by prior experiments. As far as renal function is concerned, there were no consistent differences between the anesthetized and unanesthetized animals. All blood samples were obtained from an indwelling needle in the femoral artery with heparin as an anticoagulant. The plasma was promptly separated after centrifugation. Exogenous creatinine clearance with plasma levels from 15 to $45 \mathrm{mg}$ per $100 \mathrm{ml}$ was used as a measure of filtration rate; the clearance of $p$-aminohippurate $(\mathrm{PAH})$ at plasma levels of less than $2 \mathrm{mg}$ per $100 \mathrm{ml}$ was used as an index of effective renal plasma flow. In some experiments ultrafiltrates of plasma were prepared by the method of Toribara, Terepka and Dewey (18) at $37^{\circ} \mathrm{C}$ with a gas phase of 5 per cent $\mathrm{CO}_{2}$; these estimates were made for at least two out of every three periods.

Quinine was estimated by the double extraction procedure used by Orloff and Berliner (4), except that the final solution was read spectrophotometrically $(250 \mathrm{~m} \mu)$. Recovery of the drug added to plasma and urine averaged 95 per cent. Appropriate corrections for blanks were made in each experiment for concentration in plasma and amounts in urine, calculated as excretion per minute; these were always less than 5 per cent of the measured amount in urine and approximately 20 per cent of that for plasma. The specificity of the analysis was confirmed by the method of Brodie and Udenfriend (19). In the relative quantities encountered, none of the other bases interfered with the method for quinine.

Tetraethyl ammonium (TEA) was measured by the method of Rennick, Calhoon, Gandia and Moe (20). Since recoveries with this method are not complete, each set of analyses was run with simultaneous standards added to blank plasmas and urines taken from the dog prior to drug administration. Blank values were themselves negligible, as is protein binding (16). In the amounts encountered in the experiments, quinine showed no interference with this method.

Tolazoline $\mathrm{HCl}$ (Priscoline) was obtained as the pure powder from Ciba Pharmaceutical Products, Inc. This was determined by the methyl orange method used by Orloff, Aranow and Berliner (12), based on the procedure of Brodie, Aranow and Axelrod (21), who established its validity for dog urine and plasma. Since only a relatively small amount is protein bound (21), the degree of binding was not determined in the present experiments. Quinine is also measured by this method, and it was necessary to correct the apparent tolazoline concentration for the actual amount of quinine present in each sample as determined above. This correction amounted to approximately 40 per cent of the total chromogen for plasma and less than 20 per cent for urine. The maximal errors inherent in these corrections are negligible relative to the excretion rates or to the changes in excretion that were produced by the administration of quinine as the inhibitor base (see Table II). 
TABLE I

Inhibition of tetraethyl ammonium (TEA) excretion by quinine *

\begin{tabular}{|c|c|c|c|c|c|c|c|c|c|c|}
\hline \multirow[b]{2}{*}{ Time } & \multirow[b]{2}{*}{$\mathrm{V}$} & \multirow[b]{2}{*}{ GFR } & \multirow{2}{*}{$\begin{array}{c}\text { Urine } \\
\mathrm{pH}\end{array}$} & \multicolumn{4}{|c|}{ TEA } & \multirow{2}{*}{$\frac{\mathrm{C}_{\mathrm{TEA}}}{\mathrm{GFR}}$} & \multicolumn{2}{|c|}{ Quinine } \\
\hline & & & & $\mathrm{P}$ & UV & $\mathrm{UV} / \mathrm{P}$ & $\mathrm{T} \dagger$ & & $\mathbf{P}$ & $\mathrm{UV} / \mathrm{P}$ \\
\hline $\min$ & \multicolumn{2}{|c|}{$m l / \min$} & & $\mu g / m l$ & $m g / \min$ & $\mathrm{ml} / \mathrm{min}$ & $m g / m i n$ & & $\mu g / m l$ & $\mathrm{ml} / \mathrm{min}$ \\
\hline-52 to -33 & \multicolumn{10}{|c|}{ Priming infusion: $400 \mathrm{ml} \mathrm{5 \%}$ mannitol and $0.4 \%$ creatinine, containing $48 \mathrm{mg}$ TEA } \\
\hline-33 & \multicolumn{10}{|c|}{ Infuse $5 \%$ mannitol and $0.4 \%$ creatinine at $10 \mathrm{ml} / \mathrm{min}$ with added TEA at $5 \mathrm{mg} / \mathrm{min}$} \\
\hline $\begin{array}{r}0-10 \\
10-20 \\
20-30\end{array}$ & $\begin{array}{l}5.4 \\
5.4 \\
5.1\end{array}$ & $\begin{array}{l}44 \\
46 \\
44\end{array}$ & $\begin{array}{l}6.89 \\
6.89 \\
6.86\end{array}$ & $\begin{array}{l}15.5 \\
19.8 \\
22.2\end{array}$ & $\begin{array}{l}2.07 \\
1.99 \\
1.88\end{array}$ & $\begin{array}{r}133 \\
100 \\
85\end{array}$ & $\begin{array}{l}1.38 \\
1.08 \\
0.90\end{array}$ & $\begin{array}{l}3.07 \\
2.19 \\
1.94\end{array}$ & & \\
\hline $30-45$ & \multicolumn{10}{|c|}{ Inject $625 \mathrm{mg}$ quinine $\mathrm{HCl}$} \\
\hline 30 & \multicolumn{10}{|c|}{$\begin{array}{l}\text { Continue sustaining infusion, adjust TEA to } 2.7 \mathrm{mg} / \mathrm{min} \text { and add quinine } \mathrm{HCl} \text { to provide } 13.0 \mathrm{mg} / \\
\text { min }\end{array}$} \\
\hline $\begin{array}{l}60-70 \\
70-80 \\
80-90\end{array}$ & $\begin{array}{l}5.1 \\
4.7 \\
4.5\end{array}$ & $\begin{array}{l}39 \\
37 \\
35\end{array}$ & $\begin{array}{l}6.85 \\
6.79 \\
6.69\end{array}$ & $\begin{array}{l}28.0 \\
27.4 \\
29.2\end{array}$ & $\begin{array}{l}1.36 \\
1.30 \\
1.27\end{array}$ & $\begin{array}{l}48.5 \\
47.5 \\
43.5\end{array}$ & $\begin{array}{l}0.26 \\
0.29 \\
0.26\end{array}$ & $\begin{array}{l}1.24 \\
1.29 \\
1.26\end{array}$ & $\begin{array}{l}13.4 \\
14.6 \\
14.9\end{array}$ & $\begin{array}{l}28.5 \\
28.6 \\
27.6\end{array}$ \\
\hline
\end{tabular}

* A $15.6 \mathrm{~kg}$ dog anesthetized with pentobarbital.

$\dagger \mathrm{T}$ (tubular transport) has been calculated as the difference between the amounts excreted and filtered.

Pempidine (22) and mecamylamine (14) were each estimated by the same procedure used for tolazoline. Complete recovery of these compounds is obtained by this extraction procedure. The absence of appreciable quantities of metabolites in short-term experiments has been indicated by Baer and co-workers (14) for mecamylamine. Pempidine excreted in the urine, as measured by this procedure, showed the same $\mathrm{pH}$ dependence as the authentic compound for its partition coefficient between chloroform and buffers, indicating the absence of significant amounts of interfering metabolites in the urine.
The correction for the presence of quinine is similar to that indicated above. Protein binding of pempidine is about 20 per cent in the dog, but clearances have not been corrected for this binding. Mepiperphenidol interferes with the usual procedure for pempidine and mecamylamine. This difficulty can be overcome by washing the organic phase with one-fourth vol of $0.16 \mathrm{M}$ borate buffer, $\mathrm{pH}$ 9.1, after the initial amine extraction. This procedure reduces the interference to negligible values without associated loss of the amine.

At the time that the inhibitor base was administered,

TABLE II

Inhibition of tolazoline excretion by quinine *

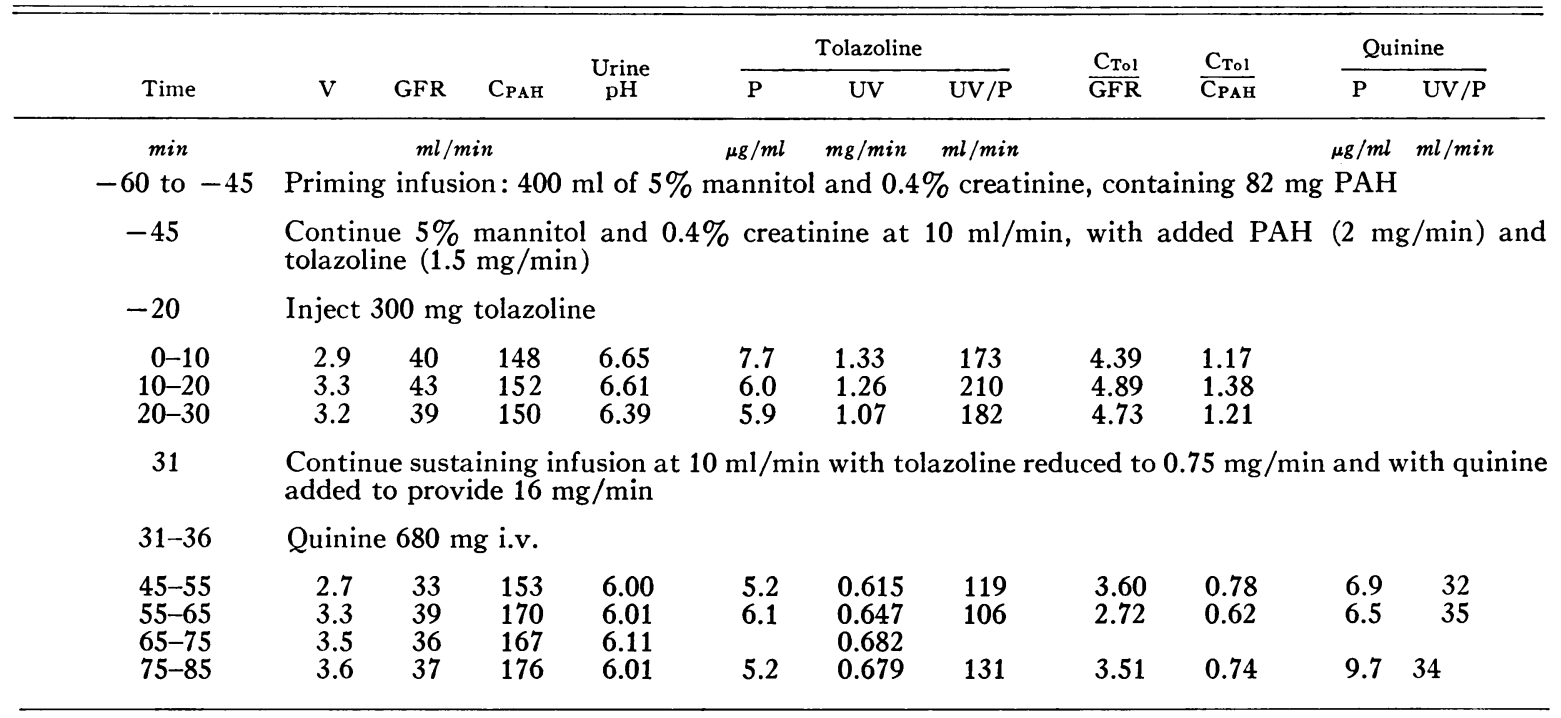

*A $16 \mathrm{~kg}$ dog anesthetized with pentobarbital. 
TABLE III

Inhibition of pempidine excretion by mepiperphenidol *

\begin{tabular}{|c|c|c|c|c|c|c|c|c|c|}
\hline \multirow[b]{2}{*}{ Time } & \multirow[b]{2}{*}{$\mathbf{V}$} & \multirow[b]{2}{*}{ GFR } & \multirow[b]{2}{*}{ CPAH $_{\text {PAH }}$} & \multirow{2}{*}{$\begin{array}{c}\text { Urine } \\
\text { pH }\end{array}$} & \multicolumn{3}{|c|}{ Pempidine } & \multirow{2}{*}{$\frac{C_{\text {Pemp }}}{\text { GFR }}$} & \multirow{2}{*}{$\frac{C_{\text {Pemp }}}{C_{\text {PAR }}}$} \\
\hline & & & & & $\mathbf{P}$ & UV & $\mathrm{UV} / \mathrm{P}$ & & \\
\hline $\min$ & \multirow{2}{*}{\multicolumn{9}{|c|}{ 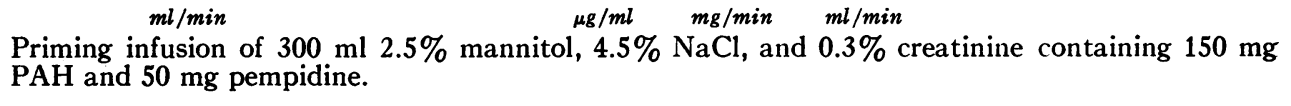 }} \\
\hline-81 to -74 & & & & & & & & & \\
\hline-74 & \multicolumn{9}{|c|}{$\begin{array}{l}\text { Start sustaining infusion }(7 \mathrm{ml} / \mathrm{min}) 5 \% \text { mannitol, } 0.2 \% \text { creatinine with } \mathrm{PAH}(1.4 \mathrm{mg} / \mathrm{min}) \text { and } \\
\text { pempidine at } 1.7 \mathrm{mg} / \mathrm{min}\end{array}$} \\
\hline-50 to -48 & \multicolumn{9}{|c|}{ Inject $100 \mathrm{ml} 0.15 \mathrm{~N} \mathrm{NaHCO}$} \\
\hline $\begin{array}{l}0-5 \\
5-10 \\
10-15\end{array}$ & $\begin{array}{l}6.8 \\
5.6 \\
8.2\end{array}$ & $\begin{array}{l}34 \\
32 \\
37\end{array}$ & $\begin{array}{r}95 \\
84 \\
109\end{array}$ & $\begin{array}{l}6.87 \\
6.87 \\
6.86\end{array}$ & $\begin{array}{l}7.1 \\
7.2 \\
7.7\end{array}$ & $\begin{array}{l}0.700 \\
0.666 \\
0.865\end{array}$ & $\begin{array}{r}99 \\
93 \\
112\end{array}$ & $\begin{array}{l}2.92 \\
2.95 \\
3.01\end{array}$ & $\begin{array}{l}1.04 \\
1.11 \\
1.03\end{array}$ \\
\hline 15 & \multicolumn{9}{|c|}{$\begin{array}{l}\text { Change sustaining infusion. Same composition as above, except pempidine reduced to } 1.0 \mathrm{mg} / \mathrm{min} \text {, } \\
\text { mepiperphenidol added at rate of } 2.5 \mathrm{mg} / \mathrm{min} \text {, and } \mathrm{HCl} \text { added at rate of } 0.4 \mathrm{mEq} / \mathrm{min}\end{array}$} \\
\hline $16-23$ & \multicolumn{9}{|c|}{ Mepiperphenidol 65 mg i.v. } \\
\hline $\begin{array}{l}30-35 \\
35-40 \\
45-50\end{array}$ & $\begin{array}{l}7.6 \\
8.0 \\
6.0\end{array}$ & $\begin{array}{l}32 \\
34 \\
28\end{array}$ & $\begin{array}{r}99 \\
108 \\
94\end{array}$ & $\begin{array}{l}6.65 \\
6.56 \\
6.49\end{array}$ & $\begin{array}{l}9.4 \\
8.7 \\
9.1\end{array}$ & $\begin{array}{l}0.590 \\
0.626 \\
0.556\end{array}$ & $\begin{array}{l}63 \\
72 \\
61\end{array}$ & $\begin{array}{l}1.95 \\
2.12 \\
2.17\end{array}$ & $\begin{array}{l}0.64 \\
0.67 \\
0.65\end{array}$ \\
\hline
\end{tabular}

* A $12 \mathrm{~kg}$ dog without anesthesia.

the rate of infusion of substrate base was reduced so that the plasma levels of substrate base would remain as constant as possible.

\section{RESULTS}

A total of 49 clearance experiments was done, of which 29 were designed to study competitive inhibition, and the remainder to study effects of urine $\mathrm{pH}$ and volume.

Competitive inhibition. Of the 29 experiments performed, in 14 the results were consistent with competition between bases for tubular secretion. Each protocol was similar to those shown in Tables I to III. Results of the positive experiments are summarized in Table IV. The base under study (substrate base) was infused so as to obtain a constant plasma level and excretion rate. The potential competitor (inhibitor base) was then administered in a large priming dose followed by a sustaining infusion. The dose of each could be varied only over a very limited range, the minimal amount being determined by the analytical methods, the maximal by the toxicity of the compound.

In 3 experiments, quinine (an amine) inhibited the excretion of TEA (an onium compound), as shown in Table I. In 3 experiments quinine decreased the excretion of tolazoline, another amine (see Table II). In a single experiment quinine inhibited pempidine excretion. In 3 experiments the excretion of mecamylamine (an amine) decreased slightly after the administration of mepiperphenidol (an onium compound). In 4 experiments, the excretion of pempidine (an amine) was inhibited by mepiperphenidol (see Table III). It should be noted in the protocols that urine volume remained virtually the same in the experimental and control periods. Urine $\mathrm{pH}$ was somewhat more difficult to control, but in each acceptable study the experimental periods had a $\mathrm{pH}$ the same as or lower than the controls. This may minimize any changes in excretion that might result from inhibition of secretion, since a more acid tubular fluid would decrease reabsorption by non-ionic diffusion and hence augment excretion.

It is probable that the degree of inhibition depends on the concentration of inhibitor base relative to that of substrate base. Thus, the magnitude of inhibition might be increased if substrate base had been administered in trace amounts, for example as a radioactive compound. Our results with mepiperphenidol and mecamylamine are of borderline significance. A much greater degree of inhibition was obtained by Smith and associates (17), using smaller quantities of substrate base labeled with isotope.

The correct parameter for the evaluation of 
changes in tubular secretion is not readily evident. Quinine has been previously shown to increase renal plasma flow and decrease the filtration fraction (23). The filtration rate itself is conventionally used as the reference point for the evaluation of changes in tubular activity. However, in considering a secretory phenomenon, the renal plasma flow may for some purposes serve as a more valid reference, particularly when the filtration fraction is itself changing. In 5 experiments with different bases as substrates, the administration of quinine produced a 41 per cent fall in clearance ratio with the filtration rate as the reference point. but a 53 per cent decrease when referred to the simultaneous renal plasma flow $\left(\mathrm{C}_{\mathrm{PAH}}\right)$. These changes were consistent and reflect a dual action of quinine; i.e., both renal vasodilation leading to a decrease in filtration fraction (from 0.29 to 0.23 ), and a simultaneous inhibition of the tubular secretion of the substrate base. The latter phenomenon is best evaluated by reference to the clearance of $\mathrm{PAH}$ rather than to that of creatinine, since the control clearance appears to be largely limited by renal plasma flow. Mepiperphenidol, unlike quinine, did not cause any consistent changes in filtration fraction.

Of the remaining 14 experiments, which were designed to demonstrate competitive inhibition, 8 were done with quinine as the substrate base and with the following as the potential inhibitor: the cyanine dye no. $863^{3}$ ( $5 \mathrm{mg}$ per $\mathrm{kg}$ ); tolazoline ( $37 \mathrm{mg}$ per $\mathrm{kg}$ ); tetra- $n$-butyl ammonium iodide (12 $\mathrm{mg}$ per $\mathrm{kg}$ ); and mepiperphenidol (5 $\mathrm{mg}$ per $\mathrm{kg}$ ). The dose of quinine was $20 \mathrm{mg}$ per $\mathrm{kg}$, which yielded plasma levels of about $4 \mu \mathrm{g}$ per $\mathrm{ml}$. Quinine excretion decreased in a few experiments but was attributed to a rise in urinary $\mathrm{pH}$. Otherwise the experiments were negative. Presumably, quinine has a greater affinity for the transport system than the potential inhibitor, at least in the relative doses employed.

In 3 experiments quinine was administered with mecamylamine as substrate. This combination of agents was too toxic and the animals died before meaningful measurements could be obtained. The remaining 3 experiments were carried out with various combinations of bases and, although excretion of substrate base decreased, the experiments were inconclusive because of a rise in urinary $\mathrm{pH}$.

Net tubular secretion of quinine. Net tubular secretion of amines has been demonstrated in the dog by the excretion of an amount significantly in excess of that which is filtered. This has been shown for tolazoline (12), mecamylamine (14), pempidine, and two isocamphane derivatives (6). In the case of quinine, the competitive phenomena

${ }^{3} \mathrm{We}$ are indebted to Dr. L. G. S. Booker of the Eastman Kodak Company for a generous supply of the cyanine dye.

TABLE IV

Summary of experiments demonstrating competitive inhibition of excretion of organic bases *

\begin{tabular}{|c|c|c|c|c|c|c|c|c|c|}
\hline \multicolumn{2}{|c|}{ Organic base } & \multirow{2}{*}{$\begin{array}{c}\text { Urine } \\
\mathrm{pH} \\
\Delta\end{array}$} & \multicolumn{2}{|c|}{ V/GFR } & & \multicolumn{2}{|c|}{$\mathrm{C}_{\text {Base/GFR }}$} & \multicolumn{2}{|c|}{$\mathrm{C}_{\text {Base }} / \mathrm{C}_{\mathrm{PAH}}$} \\
\hline Substrate & Inhibitor & & Control & Exp. & & Control & Exp. & Control & Exp. \\
\hline TEA & Quinine & -0.1 & 0.13 & 0.11 & & 3.2 & 2.3 & & \\
\hline TEA & Q̌uinine & -0.1 & 0.12 & 0.13 & & 2.4 & 1.3 & & \\
\hline TEA & Quinine & -0.4 & 0.13 & 0.14 & & 2.2 & 1.5 & 0.54 & 0.27 \\
\hline Tolazoline & Quinine & -0.5 & 0.08 & 0.09 & & 4.6 & 3.3 & 1.20 & 0.72 \\
\hline Tolazoline & Quinine & 0 & 0.09 & 0.09 & & 3.7 & 3.1 & 1.20 & 0.70 \\
\hline Tolazoline & Quinine & -0.1 & 0.10 & 0.14 & & 4.6 & 2.3 & 0.95 & 0.32 \\
\hline Pempidine & Quinine & -0.1 & 0.12 & 0.16 & & 2.8 & 2.3 & 1.10 & 0.69 \\
\hline Pempidine & Darstine $\dagger$ & 0 & 0.14 & 0.15 & & 2.5 & 1.3 & 0.92 & 0.42 \\
\hline Pempidine & Darstine & -0.3 & 0.18 & 0.17 & i & 2.7 & 1.8 & 1.01 & 0.66 \\
\hline Pempidine & Darstine & -0.3 & 0.20 & 0.22 & & 3.0 & 2.0 & 1.06 & 0.66 \\
\hline Pempidine & Darstine & -0.2 & 0.24 & 0.34 & & 4.2 & 2.7 & 1.29 & 0.96 \\
\hline Mecamylamine & Darstine & -0.4 & 0.11 & 0.14 & & 2.9 & 2.6 & 1.20 & 0.97 \\
\hline Mecamylamine & Darstine & -0.4 & 0.22 & 0.16 & & 3.8 & 2.6 & 0.98 & 0.71 \\
\hline Mecamylamine & Darstine & -0.1 & 0.37 & 0.34 & & 3.9 & 3.3 & 1.04 & 0.93 \\
\hline
\end{tabular}

* Results are average values for control and experimental periods. Urine $\mathrm{pH} \Delta$ indicates experimental periods were more acid than control (no change in 2). Very high values for V/GFR were obtained during mannitol diuresis. $\mathrm{C}_{\text {Base }}$ refers to substrate organic base.

$\dagger$ Mepiperphenidol was given as Darstine (Merck Sharp \& Dohme). 
TABLE $V$

Renal clearance of quinine in the dog *

\begin{tabular}{|c|c|c|c|c|c|c|c|c|c|}
\hline \multirow[b]{3}{*}{ Dog } & \multirow[b]{3}{*}{ Wt } & \multirow[b]{3}{*}{ V } & \multirow[b]{3}{*}{ GFR } & \multirow{2}{*}{\multicolumn{2}{|c|}{$\mathrm{pH}$}} & \multicolumn{4}{|c|}{ Quinine } \\
\hline & & & & & & \multirow[b]{2}{*}{$\mathrm{P}$} & \multirow[b]{2}{*}{$\mathrm{F} / \mathrm{P}$} & \multirow{2}{*}{$\frac{\mathrm{UV} / \mathrm{P}}{\mathrm{GFR}}$} & \multirow{2}{*}{$\frac{\mathrm{UV} / \mathrm{F}}{\mathrm{GFR}}$} \\
\hline & & & & Urine & Blood & & & & \\
\hline & $\mathrm{kg}$ & \multicolumn{2}{|c|}{$m l / \min$} & & & $\mu g / m l$ & & & \\
\hline Lo & 14 & 3.6 & 49 & $4.9-5.0$ & 7.40 & 4.4 & 0.22 & 0.95 & 4.32 \\
\hline $\mathrm{Ta}$ & 19 & 5.3 & 64 & $5.1-5.1$ & 7.40 & 3.1 & 0.36 & 1.46 & 4.06 \\
\hline Lo & 14 & 3.6 & 44 & $5.7-5.9$ & 7.40 & 5.4 & 0.36 & 1.09 & 3.03 \\
\hline $\mathrm{Be}$ & 30 & 13.4 & 100 & $6.8-6.9$ & 7.39 & 4.7 & 0.34 & 0.85 & 2.50 \\
\hline $\mathrm{Ta}$ & 17 & 26.4 & 87 & $7.1-7.2$ & 7.46 & 3.8 & 0.45 & 0.98 & 2.18 \\
\hline Lo & 14 & 16.6 & 48 & $7.1-7.2$ & 7.42 & 4.9 & 0.35 & 0.68 & 1.94 \\
\hline $\mathrm{Pa}$ & 17 & 3.8 & 47 & $7.0-7.4$ & & 6.4 & 0.21 & 0.34 & 1.64 \\
\hline $\mathrm{Be}$ & 30 & 3.1 & 76 & $4.9-5.0$ & 7.35 & 2.4 & & 1.95 & \\
\hline Bl & 12 & 5.8 & 26 & $5.0-5.1$ & & 4.7 & & 1.82 & \\
\hline $\mathrm{Pr}$ & 17 & $\begin{array}{l}0.0 \\
3.7\end{array}$ & 34 & $5.2-5.4$ & & 4.4 & & 1.23 & \\
\hline $\mathrm{Pl}$ & 13 & 4.5 & $\begin{array}{l}34 \\
34\end{array}$ & $5.7-5.8$ & & 3.7 & & 1.18 & \\
\hline Lo & $\begin{array}{l}13 \\
14\end{array}$ & $\begin{array}{l}4.5 \\
2.7\end{array}$ & $\begin{array}{l}34 \\
54\end{array}$ & $5.0-5.4$ & & 4.2 & & 1.02 & \\
\hline Sa & 16 & 5.3 & 41 & $6.4-6.5$ & & 9.3 & & 0.85 & \\
\hline $\mathrm{Su}$ & 13 & 3.5 & 34 & $5.9-5.9$ & & 4.9 & & 0.52 & \\
\hline
\end{tabular}

* $\mathrm{F} / \mathrm{P}$ designates concentration ratio for ultrafiltrate of plasma and plasma, respectively. $\mathrm{UV} / \mathrm{F}$ is conventional clearance corrected for plasma protein binding. Values are average of 3 consecutive clearance periods; range of urine $\mathrm{pH}$ is given.

described above are compatible with its own secretion by the tubule. However, unequivocal evidence for secretion has not previously been reported. Our results are summarized in Table V. In 7 experiments the quinine clearance, uncorrected for plasma protein binding, was greater than the filtration rate. At these plasma levels, quinine is about one-third free and two-thirds protein bound. Thus, when the ratios are corrected for binding, net tubular secretion of quinine was demonstrable in virtually every experiment. In the experiments, the urinary $\mathrm{pH}$ was from 4.9 to 7.4 , and within this range the $\mathrm{pH}$ dependence of quinine excretion was confirmed. Orloff and Berliner (4) have previously demonstrated net tubular reabsorption of quinine in a strongly alkaline urine.

$p H$ Dependence of tolazoline. Previous studies by Orloff and colleagues (12) have shown a maximal rate of net tubular secretion $(\mathrm{Tm})$ for tolazoline in the dog. This suggested an active secretory mechanism, a concept which has been substantiated by the competitive inhibition experiments described above. However, in relation to the general hypothesis of both secretion and reabsorption, it was important to ascertain whether the excretion of tolazoline is $\mathrm{pH}$ dependent. As shown in Table VI, this compound is qualitatively similar to other amines in that its excretion is diminished in an alkaline urine. Calculation of a secretory $\mathrm{Tm}$ as the difference between the amounts excreted and filtered, therefore, yields only an apparent value.

Volume dependence. Scribner, Crawford and Dempster (6) have shown that the excretion of amines may be increased during mannitol diuresis despite a moderate rise in urine $\mathrm{pH}$. Orloff and Berliner (4) had found a similar effect with quinine and the antimalarial SN-8439 in relatively alkaline urines. This has been interpreted as evidence for non-ionic diffusion in a reabsorptive direction. The experiments of Scribner and associates were complicated by reduction in both renal plasma flow and filtration rate during the periods of high urine flow, presumably due to the hemodynamic effects of the infused amines.

The phenomenon has therefore been re-examined in 5 experiments with pempidine. Osmotic diuresis was produced with mannitol, and urine $\mathrm{pH}$ was kept as constant as possible. In all experiments the mannitol infusion produced a marked rise in renal plasma flow with a fall in filtration fraction; filtration rate remained constant. With aciduria, the clearance of pempidine increased with increasing urine flow despite a slight rise in urine $\mathrm{pH}$. However, this is difficult to interpret, since the ratio of pempidine to $\mathrm{PAH}$ clearance remained constant, at almost unity. This suggests that with aciduria the clearance of the amine may be limited by blood flow. Hence, 
TABLE VI

Effect of urinary $p H$ on renal excretion of tolazoline *

\begin{tabular}{|c|c|c|c|c|c|c|c|c|c|c|}
\hline \multirow[b]{2}{*}{ Time } & \multirow[b]{2}{*}{$\mathrm{V}$} & \multirow[b]{2}{*}{ GFR } & \multirow[b]{2}{*}{$\mathrm{C}_{\mathrm{PAH}}$} & \multirow[b]{2}{*}{$\begin{array}{l}\text { Urine } \\
\mathrm{pH}\end{array}$} & \multicolumn{4}{|c|}{ Tolazoline } & \multirow[b]{2}{*}{$\frac{\mathrm{C}_{\mathrm{Tol}}}{\mathrm{GFR}}$} & \multirow[b]{2}{*}{$\frac{\mathrm{C}_{\mathrm{Tol}}}{\mathrm{C}_{\mathrm{PAH}}}$} \\
\hline & & & & & $\mathbf{P}$ & UV & $\mathrm{UV} / \mathrm{P}$ & $\underset{\mathrm{T} \dagger}{\text { Apparent }}$ & & \\
\hline $\min$ & & \multicolumn{2}{|c|}{$\mathrm{ml} / \mathrm{min}$} & & $\mu g / m l$ & $m g / m i n$ & $m l / m i n$ & \multicolumn{2}{|c|}{$m g / m i n$} & \\
\hline-65 to -60 & \multicolumn{10}{|c|}{$\begin{array}{l}\text { Priming infusion: } 125 \mathrm{ml} \text { of } 5 \% \text { mannitol containing } 1.5 \mathrm{~g} \text { creatinine, } 70 \mathrm{mg} \text { PAH, } 260 \mathrm{mg} \text { tolazo- } \\
\text { line. }\end{array}$} \\
\hline-60 & \multicolumn{10}{|c|}{$\begin{array}{l}\text { Start sustaining infusion at } 1.3 \mathrm{ml} / \mathrm{min} \text { of } 5 \% \text { mannitol with creatinine }(20 \mathrm{mg} / \mathrm{min}), \text { PAH (3.8 } \\
\mathrm{mg} / \mathrm{min}) \text {, and tolazoline }(1.4 \mathrm{mg} / \mathrm{min})\end{array}$} \\
\hline $\begin{array}{r}0-10 \\
10-20 \\
20-30\end{array}$ & $\begin{array}{l}0.80 \\
0.75 \\
0.80\end{array}$ & $\begin{array}{l}45 \\
39 \\
47\end{array}$ & $\begin{array}{l}122 \\
115 \\
139\end{array}$ & $\begin{array}{l}5.61 \\
5.79 \\
5.53\end{array}$ & $\begin{array}{l}9.8 \\
9.6 \\
9.9\end{array}$ & $\begin{array}{l}1.49 \\
1.40 \\
1.44\end{array}$ & $\begin{array}{l}152 \\
146 \\
146\end{array}$ & $\begin{array}{l}1.05 \\
1.03 \\
0.98\end{array}$ & $\begin{array}{l}3.36 \\
3.77 \\
3.13\end{array}$ & $\begin{array}{l}1.25 \\
1.27 \\
1.05\end{array}$ \\
\hline 30 & \multicolumn{10}{|c|}{ Stop sustaining infusion } \\
\hline $30-50$ & \multicolumn{10}{|c|}{ Infuse $500 \mathrm{ml}$ of $0.3 \mathrm{M} \mathrm{NaHCO}_{3}$ with $400 \mathrm{mg}$ creatinine, $40 \mathrm{mg}$ tolazoline, and $27 \mathrm{mg} \mathrm{PAH}$} \\
\hline 50 & \multicolumn{10}{|c|}{$\begin{array}{l}\text { Start new sustaining infusion at } 1.3 \mathrm{ml} / \mathrm{min} \text { of } 0.3 \mathrm{M} \mathrm{NaHCO} \text { with creatinine }(20 \mathrm{mg} / \mathrm{min}) \text {, } \\
\text { PAH }(3.8 \mathrm{mg} / \mathrm{min}) \text {, and tolazoline }(1.9 \mathrm{mg} / \mathrm{min})\end{array}$} \\
\hline $\begin{array}{l}70-80 \\
80-90 \\
90-100\end{array}$ & $\begin{array}{l}2.2 \\
2.1 \\
2.1\end{array}$ & $\begin{array}{l}57 \\
50 \\
53\end{array}$ & $\begin{array}{l}156 \\
146 \\
158\end{array}$ & $\begin{array}{l}7.67 \\
7.80 \\
7.88\end{array}$ & $\begin{array}{l}8.9 \\
8.3 \\
9.6\end{array}$ & $\begin{array}{l}0.956 \\
0.929 \\
0.996\end{array}$ & $\begin{array}{l}108 \\
112 \\
104\end{array}$ & $\begin{array}{l}0.45 \\
0.52 \\
0.49\end{array}$ & $\begin{array}{l}1.93 \\
2.24 \\
1.97\end{array}$ & $\begin{array}{l}0.69 \\
0.77 \\
0.66\end{array}$ \\
\hline
\end{tabular}

* A $17 \mathrm{~kg}$ dog without anesthesia.

$\dagger \mathrm{T}=$ tubular transport.

the increased clearance does not necessarily indicate a decrease in tubular reabsorption due to an increase in urine flow rate. However, with more alkaline urines (above $\mathrm{pH} 7$ ) the absolute clearance of pempidine was not limited by renal blood flow. In an experiment with an initial urine $\mathrm{pH}$ of 7.25 and $V / G F R$ of 0.03 , the pempidine clearance/GFR was 0.74 ; at maximal diuresis, urine $\mathrm{pH}$ was $7.34, \mathrm{~V} / \mathrm{GFR}$ was 0.23 , and the clearance ratio had risen to 1.26. Glomerular filtration rates were 42 and $41 \mathrm{ml}$ per minute, respectively. Thus, there was net tubular reabsorption at low urine flows and net tubular secretion at high rates of flow. These results are consistent with the interpretation of others-namely, that reabsorption is dependent on the concentration of the base in the tubular fluid.

\section{DISCUSSION}

Evidence for active secretion. Under conditions in which decreased excretion cannot be attributed to an increase in reabsorption by diffusion, the administration of one organic base decreases the excretion of another. This was observed in a total of 14 experiments; it is interpreted as competition for secretion by active tubular transport. An amine can inhibit another amine (quinine inhibits tolazoline and pempidine); an amine can inhibit an onium compound (quinine inhibits TEA); and an onium compound can inhibit an amine (mepiperphenidol inhibits mecamylamine and pempidine). Previous studies (11) have demonstrated competition between quaternary compounds in the renal portal system of the chicken. In addition, competition between tolazoline (an amine) and several onium bases has been demonstrated in the chicken (13). Taken in their entirety the findings indicate that both amines and onium compounds are secreted by the same active transport system. Since the onium bases may be considered as completely ionized in aqueous solutions, it is probable that both classes of compounds are secreted as ionized particles. In this respect the transport system may be similar to that for organic acids. However, separate systems exist for bases and acids as indicated by competition and inhibitor studies (11).

The nature of the $p H$-dependent process. While many authors regard $\mathrm{pH}$ dependence as an example of non-ionic diffusion through a lipid-like membrane (5), others have suggested that it represents an active transport system whose activity or direction is determined by hydrogen ion 
concentration $(14,24)$. As will be discussed below, the present interpretations do not agree with previous conclusions that non-ionic diffusion is the sole determinant of both net tubular secretion and net tubular reabsorption. Nevertheless, the evidence indicates that the $\mathrm{pH}$-dependent process (in a reabsorptive direction) is one of diffusion and not of active transport. The major argument proposed by others in favor of an active mechanism is that the excretion of both relatively strong acids (low $\mathrm{pKa}$ ) and bases (high $\mathrm{pKa}$ ) shows $\mathrm{pH}$ dependence, even though only a very small fraction of the compound may be uncharged at the $\mathrm{pH}$ of body fluids. Thus, in the case of mecamylamine ( $\mathrm{pKa} 11.4$ ), it has been estimated that at $\mathrm{pH} 7$ only 1 molecule in 25,000 exists as the non-ionic form (14). Hence, it has been argued that a change in the concentration of this small fraction can not influence reabsorption. A similar interpretation has been applied to the phenylbutazone series of acids (25). However, it must be remembered that this small fraction is in instantaneous equilibrium with the bulk of the compound and, as the non-ionized particle diffuses, more is immediately formed.

A definitive treatment of the problem has been presented by Waddell and Butler (26), particularly in reference to the effect of $\mathrm{pKa}$ itself. Milne, Scribner and Crawford (5) have indicated that $\mathrm{pH}$ dependence is a function of both the relative diffusibility (through the membrane) of the two species and their relative concentrations at the $\mathrm{pH}$ of the fluids in question. According to this, there is no a priori reason for considering the tubular epithelium completely impermeable to the charged particle. Strong sulfonic acids (27) and quaternary bases (28) both appear to be reabsorbed even though this process is not $\mathrm{pH}$ dependent. Therefore, it is probable that the renal tubule is permeable to both ionized and non-ionized species, but that the lipid characteristics of the membrane make it much more permeable to the non-ionic form.

The following factors thus appear to determine the extent and characteristics of back diffusion: 1) If the non-ionized form of a weak base (or acid) is much more readily diffusible (i.e., high lipid solubility) than the ionized form, then the compound will show both $\mathrm{pH}$ and volume dependence. 2) If the base is so strong that the concentration ratio, ionized to non-ionized, is extremely large and if, at the same time, the tubule is appreciably permeable to the charged form, then the excretion of the compound will not be $\mathrm{pH}$ dependent but may be volume dependent. 3) If both the charged and uncharged particles are almost entirely excluded from the membrane, as for example with $\mathrm{PAH}$, there may be virtually no back diffusion and excretion will not depend significantly on either $\mathrm{pH}$ or volume. 4) If the non-ionized particle is highly diffusible and its $\mathrm{pKa}$ is such that in the $\mathrm{pH}$ range of the urine a large fraction of the compound is non-ionized, then changes in urine $\mathrm{pH}$ will have little effect on excretion rate, but volume dependence may be demonstrable (29).

Additional evidence that $\mathrm{pH}$ affects reabsorption by diffusion rather than by an active transport system is as follows. First, in the competition experiment no instance has been observed in which the inhibitor base increased excretion of the substrate base, a result which might be anticipated if bases competed for transport in a reabsorptive direction. Second, in the case of organic acids whose plasma concentration may be greatly elevated without deleterious physiological effects, no upper limit has been detected for the quantity of compound that may be reabsorbed. This characterizes a diffusion process rather than active transport. Unfortunately, the toxicity of known bases precludes this type of experiment.

Relative contributions of diffusion and active transport. In assessing the relative roles of these two processes on the net excretion of a weak base, the following factors warrant consideration: 1) the magnitude of active secretion, 2) the extent to which diffusion reaches equilibrium across the tubular epithelium, 3) the selection of correct values for arriving at the actual urinary/plasma $(\mathrm{U} / \mathrm{P})$ ratio along the nephron, and 4$)$ the limitations posed by total renal blood flow and regional intrarenal flow. The following assumptions or concepts of renal function have been accepted as valid for this discussion. 1) Active secretion of bases is a proximal process (30). 2) Maximal acidity of the tubular fluid within the cortical portions of the nephron is taken as $\mathrm{pH}$ 6.6 on the basis of the micropuncture studies of Gottschalk, Lassiter and Mylle (31). The major $\mathrm{pH}$ change occurs beyond the distal convolution as 
the collecting duct descends to the papilla, it being assumed that studies on localization of tubular function in the rodent are applicable to the dog. 3) Diffusion is potentially bidirectional, depending on the gradient. 4) Unlike active transport, the diffusion of one compound does not significantly influence the diffusion of another. 5) The possibilities of intrarenal storage and release are neglected. 6) All segments of the nephron are considered permeable to the uncharged form and, for present purposes, impermeable to the charged. 7) For these calculations the contribution of drug in erythrocytes is neglected. 8) The changes in total osmolality produced by the countercurrent mechanism are assumed to have no effect on the $\mathrm{pH}$ of the tubular contents relative to that of the peritubular fluid.

Figure 1 summarizes the results obtained with pempidine in either an acid or alkaline urine at varying rates of urine flow. This is a relatively strong base with a $\mathrm{pKa}$ of approximately 11 (22). If the urinary concentration of total base were determined by non-ionic diffusion and if diffusion equilibrium were achieved by the time the urine was voided, then the observed $U / P$ ratio would be identical with the theoretical ratio. Thus,

$$
\frac{[\mathrm{U}]}{[\mathrm{P}]}=\frac{1+10^{\mathrm{pKa}-\mathrm{pHU}}}{1+10^{\mathrm{pKa}-\mathrm{pHP}}}
$$

in which $[\mathrm{U}]$ and $[\mathrm{P}]$ are concentrations of total (ionized plus non-ionized) base in urine and plasma, respectively. Since pempidine shows very little plasma protein binding, the ultrafiltrate concentration has been considered as identical with that of plasma.

If the observed $\mathrm{U} / \mathrm{P}$ ratio for pempidine were identical with the theoretical, as given by the equilibrium equation above, then the data would fall along the horizontal dashed line in Figure 1. It is evident that in alkaline urines the observed values are far in excess of theoretical values, while in acid urines the reverse obtains. It should be emphasized that the actual clearance is far greater with an acid than with an alkaline urine.

Many factors contribute to the deviations from theory. Aciduria may be considered first. Systemic plasma concentration has been used to estimate the observed $\mathrm{U} / \mathrm{P}$ ratio. However, the

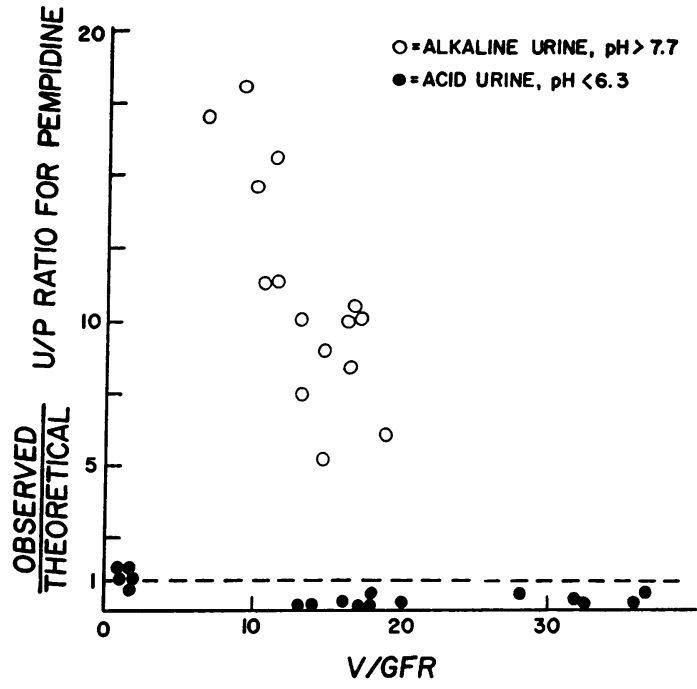

Fig. 1. EFfect of PH ON Relationship OF OBSERVED to theoretical U/P Ratio of PEMPIDINE. Since blood $\mathrm{pH}$ was not measured, a uniform value of 7.4 has been assumed. This would introduce a variable error in the theoretical ratio depending on the absolute difference between blood and urine $\mathrm{pH}$. With alkaline urines, in animals infused with sodium bicarbonate, actual blood $\mathrm{pH}$ may have been higher than the assumed level. With a urine $\mathrm{pH}$ of 7.8 , blood $\mathrm{pH}$ 's of 7.4 and 7.5 would give theoretical ratios of 0.4 and 0.5 , respectively, for a base with a $\mathrm{pKa}$ of 11 . With very acid urines, the error is even smaller. For bases with $\mathrm{pKa}$ values more than 3 logarithmic units higher than observed blood or urine $\mathrm{pH}$, the theoretical $\mathrm{U} / \mathrm{P}$ ratio is largely determined by the values for $\mathrm{pH}$. Hence, an approximate $\mathrm{pKa}$ is acceptable.

pempidine clearance in aciduria is approximately equivalent to renal plasma flow, and, hence the concentration of the drug in the peritubular capillaries must approach zero. In considering the equilibrium which might be established across the distal portion of the nephron, particularly the collecting duct, the actual ratio may be very high and might well exceed the theoretical value which has been calculated using systemic plasma.

From the experiment given in Table III, it can be seen that when active transport is inhibited, base does not diffuse into the tubular fluid in amounts sufficient to maintain a high clearance. This occurs despite a favorable $\mathrm{pH}$ gradient and an adequate concentration of drug in the peritubular plasma (calculated, on the basis of clearance, to be approximately 35 per cent of the arterial level). Two explanations are offered, both of which may be operative. First, the amount 


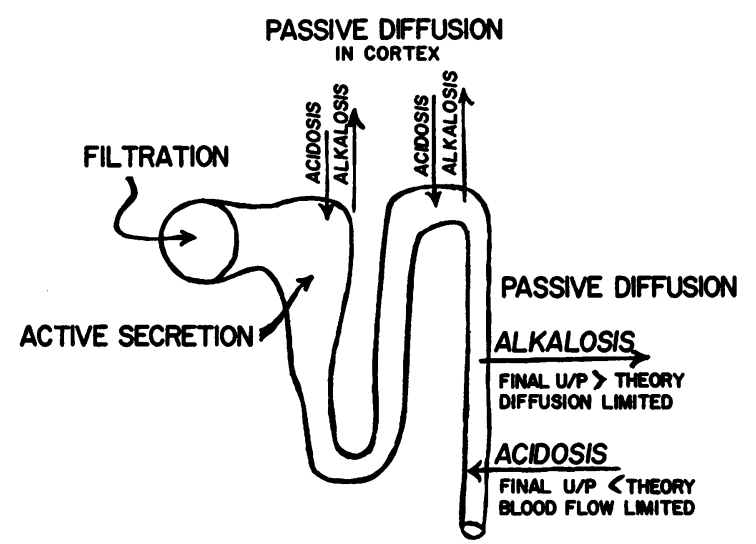

Fig. 2. Schematic RePResentation of Factors INFLUENCING RENAL EXCRETION OF TERTIARY BASES. Nonionic diffusion in the cortical part of the nephron is depicted as theoretically possible in both alkalosis and acidosis, but is negligible in amount due to diffusion limitations (see text).

of the compound delivered to the most acid region of the nephron (collecting tubule) may be limited by the medullary blood flow, which is considerably less than 10 per cent of total renal blood flow (32). From this it may be inferred that, under normal circumstances with an acid urine, only a small fraction of the excreted drug diffuses into the nephron in its most acid region. Second, diffusion equilibrium may be incomplete. If one considers the maximal degree of acidification that is possible within the cortical portions of the nephron, the magnitude of water reabsorption that takes place up to and including the distal convoluted tubule, and the amount of blood which flows to the renal cortex, it may be calculated that it is theoretically possible for organic base to be added to cortical portions of the nephron by the process of non-ionic diffusion in amounts sufficient to make the clearance of the base approximately equivalent to renal plasma flow. The calculation depends on the possibility that a tubular $\mathrm{pH}$ as low as 6.6 may be obtained by the midpoint of the proximal tubule (31). Assuming a plasma $\mathrm{pH}$ of 7.4 and a tubular fluid $\mathrm{pH}$ of 6.6 , calculations according to the equation above give a fluid/plasma concentration ratio at equilibrium of 6.3 for a base with a high pKa. Since the tubular fluid passing this segment amounts to approximately 50 per cent of the glomerular filtrate, it follows that $\frac{\mathrm{UV} / \mathrm{P}}{\mathrm{GFR}}$ would be $6.3 \times$
$50 / 100$ for this site. If there were no subsequent reabsorption of base, the clearance ratio observed in the voided urine would therefore be 3.15. Thus, it is conceivable that base may diffuse in a secretory direction before the minimal $\mathrm{pH}$ of the urine has been achieved in the most distal portion of the nephron. However, the results of experiments such as those shown in Table III indicate that if such diffusion does occur, it fails to reach equilibrium. Therefore, inward diffusion of base into the cortical nephron, even though theoretically possible, does not appear to account for a significant amount of the compound that is actually transported in a secretory direction.

In alkalosis (Figure 1) the observed ratios are greater than those predicted by theory and may involve several factors. 1) Since the final $\mathrm{pH}$ of an alkaline urine is presumably attained in the most distal portion of the nephron, it is conceivable that the base which is reabsorbed enters a relatively small volume of plasma, limited by medullary blood flow. Hence, the actual U/P ratio across the distal nephron might be closer to the theoretical value if calculated on the basis of peritubular plasma. 2) The tubular fluid in the collecting system may have a $\mathrm{pH}$ lower than that measured in the voided urine, possibly due to the delayed dehydration of carbonic acid. This would tend to decrease the discrepancy between the observed and theoretical U/P ratios. 3) The fact that the observed ratios are in excess of theory may imply that diffusion out of the tubule has not reached equilibrium in the distal nephron. This interpretation provides an explanation for the finding of Orloff and Berliner (4) that urine flow influences the excretion of amines in an alkaline but not in an acid urine. In the former, outward diffusion (amount per unit time) from the more distal segments of the nephron would be decreased by dilution of the base in a large urine volume. With aciduria, $\mathrm{pH}$-dependent diffusion would be into the lumen and would be limited by regional blood flow rather than by urine flow (Figure 2).

Others have observed a linear relationship between the logarithm of tertiary amine base excretion and urinary $\mathrm{pH}(6)$. From the above considerations, this would not appear to be the result of a true equilibrium within the nephron, 
but rather represents the net effect of multiple variables, some of which are important at one $\mathrm{pH}$, others at another. It remains to be determined to what extent different bases vary in their capacity to be secreted and in their tendency to diffuse passively.

Like other workers, we are impressed by the early speculation of Jailer, Rosenfeld and Shannon (3), who proposed the complex mechanism of active secretion and passive $\mathrm{pH}$-dependent reabsorption, even though objective evidence for this thesis was at that time virtually nonexistent. Further studies are indicated to ascertain the factors regulating the excretion of ammonia.

\section{SUMMARY}

Under conditions in which urine $\mathrm{pH}$ and volume are rigidly controlled, organic base excretion in the dog shows competitive inhibition, a phenomenon consistent with tubular secretion by active transport. Since mutual inhibition is demonstrable for both amines and onium compounds, it is inferred that both types are secreted as the charged particle. The $\mathrm{pH}$ dependence of amine excretion is attributable to non-ionic diffusion in a reabsorptive direction. Diffusion from the peritubular space into the tubular fluid cannot be rigidly excluded, but if it occurs it is limited in amount due to the relatively slow approach to diffusion equilibrium. The final concentration of organic base in the voided urine depends on multiple factors whose relative importance varies with $\mathrm{pH}$ and other experimental conditions.

\section{REFERENCES}

1. Haag, H. B., and Larsen, P. S. Studies on the fate of nicotine in the body. I. The effect of $\mathrm{pH}$ on the urinary excretion of nicotine by tobacco smokers. J. Pharmacol exp. Ther. 1942, 76, 235.

2. Haag, H. B., Larsen, P. S., and Schwartz, J. J. The effect of urinary $\mathrm{pH}$ on the elimination of quinine in man. J. Pharmacol. exp. Ther. 1943, 79, 136.

3. Jailer, J. W., Rosenfeld, M., and Shannon, J. A. The influence of orally administered alkali and acid on the renal excretion of quinacrine, chloroquine and santoquine. J. clin. Invest. 1947, 26, 1168.

4. Orloff, J., and Berliner, R. W. The mechanism of the excretion of ammonia in the dog. J. clin. Invest. 1956, 35, 223.

5. Milne, M. D., Scribner, B. H., and Crawford, M. A. Non-ionic diffusion and the excretion of weak acids and bases. Amer. J. Med. 1958, 24, 709.
6. Scribner, B. H., Crawford, M. A., and Dempster, W. J. Urinary excretion by nonionic diffusion. Amer. J. Physiol. 1959, 196, 1135.

7. Farah, A., Frazer, M., and Porter, E. Studies on the uptake of $\mathrm{N}^{\prime}$-methylnicotinamide by renal slices of the dog. J. Pharmacol. exp. Ther. 1959, 126, 202.

8. Volle, R. L., Huggins, C. G., Rodriguez, G. A., and Peters, L. Inhibition of the renal tubular transport of $\mathrm{N}^{\prime}$-methylnicotinamide (NMN) by $1,1-$ dialkylpiperidinium compounds in the avian kidney. J. Pharmacol. exp. Ther. 1959, 126, 190.

9. Green, R. E., Ricker, W. E., Attwood, W. L., Koh, Y. S., and Peters, L. Studies on the renal tubular transport characteristics of $\mathrm{N}^{\prime}$-methylnicotinamide and tetraalkylammonium compounds in the avian kidney. J. Pharmacol. exp. Ther. 1959, 126, 195.

10. Rennick, B. R., Kandel, A., and Peters, L. Inhibition of the renal tubular excretion of tetraethylammonium and $\mathrm{N}^{\prime}$-methylnicotinamide by basic cyanine dyes. J. Pharmacol. exp. Ther. 1956, 118, 204.

11. Peters, L. Renal tubular excretion of organic bases. Pharmacol. Rev. 1960, 12, 1.

12. Orloff, J., Aronow, L., and Berliner, R. W. The transport of Priscoline by the renal tubules. J. Pharmacol. exp. Ther. 1953, 109, 214.

13. Kandel, A., Green, R. E., Volle, R. L., and Peters, L. Observations concerning the renal tubular transport of Priscoline (tolazoline). J. Pharmacol. exp. Ther. 1958, 122, 327.

14. Baer, J. E., Paulson, S. F., Russo, H. F., and Beyer, K. H. Renal elimination of 3-methylaminoisocamphane hydrochloride (mecamylamine). Amer. J. Physiol. 1956, 186, 180.

15. Weiner, I. M., Washington, J. A., II, and Mudge, G. H. Studies on the renal excretion of salicylate in the dog. Bull. Johns Hopk. Hosp. 1959, 105, 284.

16. Rennick, B. R., and Farah, A. Studies on the renal tubular transport of tetraethylammonium ion in the dog. J. Pharmacol. exp. Ther. 1956, 116, 287.

17. Smith, J. M., Peake, G. T., and Peters, L. Renal excretion of organic bases. Pharmacologist 1961, $3,58$.

18. Toribara, T. Y., Terepka, A. R., and Dewey, P. A. The ultrafiltrable calcium of human serum. I. Ultrafiltration methods and normal values. J. clin. Invest. 1957, 36, 738.

19. Brodie, B. B., and Udenfriend, S. The estimation of basic organic compounds and a technique for the appraisal of specificity; application to the cinchona alkaloids. J. biol. Chem. 1945, 158, 705.

20. Rennick, B. R., Calhoon, D. M., Gandia, H., and Moe, G. K. Renal tubular secretion of tetraethylammonium in the dog and the chicken. J. Pharmacol. exp. Ther. 1954, 110, 309.

21. Brodie, B. B., Aronow, L., and Axelrod, J. The fate of benzazoline (Priscoline) in dog and man and a method for its estimation in biological material. J. Pharmacol. exp. Ther. 1952, 106, 200. 
22. Corne, S. J., and Edge, N. D. Pharmacological properties of pempidine $(1: 2: 2: 6: 6$-pentamethylpiperidine), a new ganglion-blocking compound. Brit. J. Pharmacol. 1958, 13, 339.

23. Hiatt, E. P., and Suhrie, V. Renal hyperemia in dogs induced by oral administration of cinchona alkaloids. Amer. J. Physiol. 1947, 148, 684.

24. Lotspeich, W. D. Metabolic Aspects of Renal Function. Springfield, Ill., Charles C Thomas, 1959, p. 151.

25. Gutman, A. B., Dayton, P. G., Yü, T. F., Berger, L., Chen, W., Sicam, L. E., and Burns, J. J. A study of the inverse relationship between $\mathrm{pKa}$ and rate of renal excretion of phenylbutazone analogs in man and dog. Amer. J. Med. 1960, 29, 1017.

26. Waddell, W. J., and Butler, T. C. The distribution and excretion of phenobarbital. J. clin. Invest. 1957, 36, 1217.
27. Weiner, I. M., Garlid, K. D., Romeo, J. A., and Mudge, G. H. Effects of tubular secretion and reabsorption on titration curves of tubular transport. Amer. J. Physiol. 1961, 200, 393.

28. Farah, A. Personal communication.

29. Giotti, A., and Maynert, E. W. The renal clearance of barbital and the mechanism of its reabsorption. J. Pharmacol. exp. Ther. 1951, 101, 296.

30. Rennick, B. R., and Moe, G. K. Stop-flow localization of renal tubular excretion of tetraethylammonium. Amer. J. Physiol. 1960, 198, 1267.

31. Gottschalk, C. W., Lassiter, W. E., and Mylle, M. Localization of urine acidification in the mammalian kidney. Amer. J. Physiol. 1960, 198, 581.

32. Thurau, K., Kramer, K., Deetjen, P., and Brechtelsbauer, $H$. Renal medullary blood flow and its relation to renal function. Fed. Proc. 1960, 19, 360.

\section{IMPORTANT NOTICE}

THE EDITORIAL AND BUSINESS OFFICES OF

THE JOURNAL OF CLINICAL INVESTIGATION

WILL MOVE ON

$\overline{\text { MAY 1, } 1962}$

OLD ADDRESS: THE JOURNAL OF CLINICAL INVESTIGATION

333 CEDAR STREET

NEW HAVEN 11, CONNECTICUT

NEW ADDRESS: THE JOURNAL OF CLINICAL INVESTIGATION

10 STOUGHTON STREET

BOSTON 18, MASSACHUSETTS 